\title{
The Impact of tin mining in Bangka Belitung and its reclamation studies
}

\author{
Eddy Nurtjahya ${ }^{1, *}$, Jennifer Franklin ${ }^{2}$, Umroh $^{3}$ and Fournita Agustina ${ }^{4}$ \\ ${ }^{1}$ University of Bangka Belitung, Biology Department, 33172 Merawang, Indonesia \\ ${ }^{2}$ University of Tennessee, Forestry, Wildlife and Fisheries Department, 274 Ellington Plant Sciences Building, TN 37996, USA \\ ${ }^{3}$ University of Bangka Belitung, Fisheries Department, 33172 Merawang, Indonesia \\ ${ }^{4}$ University of Bangka Belitung, Agribusiness Department, 33172 Merawang, Indonesia
}

\begin{abstract}
Tin mining in Bangka Belitung has been exploited for hundred years. The province is the second largest tin producer in the world. Secondary data from studies which took place in all four regencies in Bangka Island were discussed to show the impact of mining activities and its reclamation studies. In order to add plant selection criteria for regevetate mined soil, the greenhouse and laboratory experiment was carried out with fourteen herbs and grass species in Tennessee. The mining activities increase the wealth of the community, but the other hand they change and decrease the environmental stability, and cause horizontal conflicts. Offshore mining reduced water quality, change sea bed caused the change of biodiversity. Onshore mining activity reduces biodiversity and causes floods and damages infrastructure. While the more economic species are demanded, planting local tree species is challenging. An evaluation with local tree species concluded that best adapted species based on anatomical and physiological measurements was not those that showed the best performance in the field. The greenhouse and laboratory findings indicate that some physiological characteristics i.e. plant height and cover, transpiration rate, and foliar pigments may be used to select plant adaptability to mined soil.
\end{abstract}

\section{Introduction}

Bangka Belitung Islands produced approximately $106,000 \mathrm{t}$ of tin in 2013 or more than one third of global tin supply, and the majority is exported [1]. Tin mining is the most significant economic-driver in the province, taking place inland and offshore, including in protected forests and marine ecosystems [1].

Following the issuance of a 1999 Ministry of Trade and Industry decree that tin is not an export item to be monitored and regulated, the Bangka regent issued a decree in 2001 giving permission for the people to mine tin.

There were 80 dredges and nearly 4000 floating tin mines off the shore of Bangka Island in 2013 [2], and are up to 50,000 artisanal small scale mines (ASM) and approximately 30 independent smelters [1]. Tin production from ASM contributes up to $80 \%$ of Indonesian tin exports [3].

Tin mining activities increase the wealth of the local people, but most of the activities neglect good mining practices, safety and land reclamation [3]. The most accidents at inland mine sites are due to landslides, and non-standard diving devices [4]. The mining activity decrease the environmental stability, causes pollution, and cause horizontal conflicts. Offshore mining reduced water quality, change sea bed caused the change of biodiversity.
While the more plant species planted in mined soils in the last decade, economic species such as rubber, oil palm, and some fruit species are demanded. Planting local tree species is challenging. There is an additional challenge in cases where reclaimed soils are contaminated with metals, are highly acidic, or coarsely textured. Natural succession takes a long time [5]. Soil amendments and land preparation are the major costs [6].

An evaluation of ten native tree species concluded that four of ten species showed highest survival rates and cover development [7] but measurement of anatomical and physiological measurements of five year saplings of those species, best adapted species were not those that showed the best performance in the field (Table 1) [8].

The identification of traits that can be used to identify species for potential use in mine reclamation would greatly speed the search for appropriate native species. The early growth, pigment content, and transpiration rates of 14 herbaceous species are studied to determine whether these traits can be used to predict ground cover success on mine reclamation sites.

Anatomy and physiology parameters: stomatal density, leaf thickness, palisade thickness, sponge thickness, upper epidermal thickness, lower epidermal thickness, upper cuticle thickness, lower cuticle thickness, xylem diameter, xylem bundles, root diameter, root conductity ratio. Morphology parameters: survival rate and cover area $(1$ year old $)$, and height, stem diameter, and cover area (5 year old)

\footnotetext{
* Corresponding author: eddy_nurtjahya@yahoo.com
} 
Table 1. The most adaptive local tree species on sandy tin tailing at one and five year old based on anatomy and physiology, and morphology measurements.

\begin{tabular}{|c|c|c|}
\hline & $\begin{array}{c}\mathbf{1} \text { year old } \\
\text { [7] }\end{array}$ & $\begin{array}{c}\mathbf{5} \text { year old } \\
\text { [8] }\end{array}$ \\
\hline $\begin{array}{c}\text { Anatomy } \\
\text { and } \\
\text { Physiology }\end{array}$ & not measured & $\begin{array}{c}\text { Vitex pinnata } \\
\text { Calophyllum } \\
\text { inophyllum } \\
\text { Syzygium grande }\end{array}$ \\
\hline Morphology & $\begin{array}{c}\text { Hibiscus tiliaceus } \\
\text { Ficus superba }\end{array}$ & $\begin{array}{c}\text { Syzygium grande } \\
\text { Calophyllum } \\
\text { inophyllum } \\
\text { Vitex pinnata }\end{array}$ \\
& $\begin{array}{c}\text { Calophyllum } \\
\text { inophyllum } \\
\text { Vitex pinnata }\end{array}$ & \\
\hline
\end{tabular}

\section{Methods}

Bangka Island, with a population of nearly one million, is located off the eastern coast of South Sumatra Island [9]. The island has a surface area of $11,900 \mathrm{~km}^{2}$ and is mainly lowland below $50 \mathrm{~m}$; its climatic differences within the island are small. Its climate belonging to the Af-type Köppen-Geiger climate classification [10], with an average temperature of $26.3^{\circ} \mathrm{C}$, average humidity of $61.7 \%$ and average annual rainfall of approximately 2,400 $\mathrm{mm}[7]$.

The authors gathered secondary data from studies which took place in all four regencies in Bangka Island (Figure 1), and in the green house and laboratory in the University of Tennessee, Knoxville, USA to indicate that some physiological characteristics may be used to select plant adaptability to mined soil.

The experiment was carried out with fourteen herbs and grass species whose seeds are widely available commercially within the southeastern United States. Germination test was conducted in the laboratory, and the plants were grown in the green house. Plant height and cover were measured at weeks $2,4,6$, and 8 after seeding. Transpiration rate was measured beginning eleven weeks after planting. All analysis was completed using SPSS (C) Statistical Software (version 18.1, SPSS Inc., Chicago, USA) [28]. Leaf tissue was extracted in $80 \%(\mathrm{v} \div \mathrm{v})$ acetone for chlorophylls $\mathrm{a}$ and $\mathrm{b}[11]$, and equation of [12] for carotenoids.

\section{Socio-economic impacts}

\subsection{Positive impacts}

The positive impact of tin mining is economic [13-15]. The increase of income is shown by the number of motorcycles and cars, and from 1999 to 2011, motorcycle and car taxes increased 15-fold. The number of people who perform the hajj pilgrimage increased almost 10\% from 2001 to 2012 [16].

The income percentage for tin miners compared to overall income per month of people in Lubuk Kelik, Bangka; for ex-pepper farmers in Silip, Bangka; and for ex-rubber farmers in Bencah, Central Bangka are 90\% and above. Pepper and rubber plantations contribute less than $3 \%$ each of overall monthly income [17]. The net monthly income of fishermen in Rebo and Bubus beaches, Bangka, is just about one-third of the income of their colleagues working in tin mining [18].

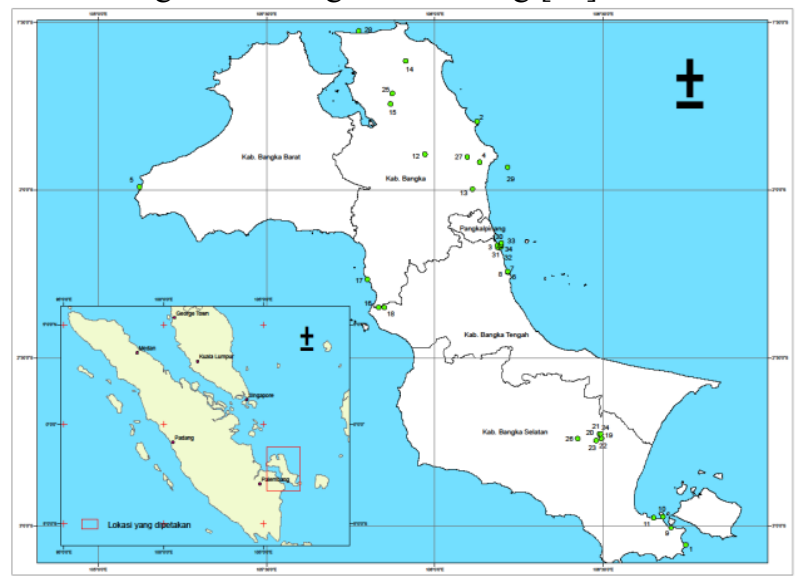

Fig. 1. Inland and offshore study sites in Bangka Island from secondary data [19]

\subsection{Negative impacts}

Tin mining also causes societal conflicts at mining sites. Most of the conflict in both inland and offshore mining is between locals and immigrants [16;4]. Attitude changes and conflicts are reported in the hamlets and villages of the studied area [19].

The drop-out rate from elementary to senior high school has increased. In 2011, the province of Bangka Belitung had the second-largest student drop-out rate in the country because of children's involvement in mining or following their parents when they move to new mining sites [16].

In some areas, fishermen and farmers have changed their professions to become miners. Fishing boats are modified to become mobile floating dredges in Bangka [18]. Rubber plantations and pepper plantations have been mined in some areas in Central Bangka and South Bangka [17].

Flooding in many areas of the province is believed to be caused by tin mining. The original small stream channels have been changed by the mining activity.

\section{Water qualities and offshore biotas}

Offshore tin mining has reduced water quality. This is shown by a $40 \%$ total soluble solid (TSS) increase, a $75 \%$ sedimentation rate increase, a $25 \%$ water $\mathrm{pH}$ decrease and a 50\% dissolved oxygen (DO) increase [20] (Figure 2). It is reported that, owing to tin mining, the concentrations of lead $(\mathrm{Pb})(0.223 \mathrm{ppm})$ and TSS in solution offshore at Batu Belubang (705 ppm) were 
above the ministerial regulations of (Kepmen LH No. 51 tahun 2004) $0.008 \mathrm{ppm}$ and $400 \mathrm{ppm}$ respectively [21].

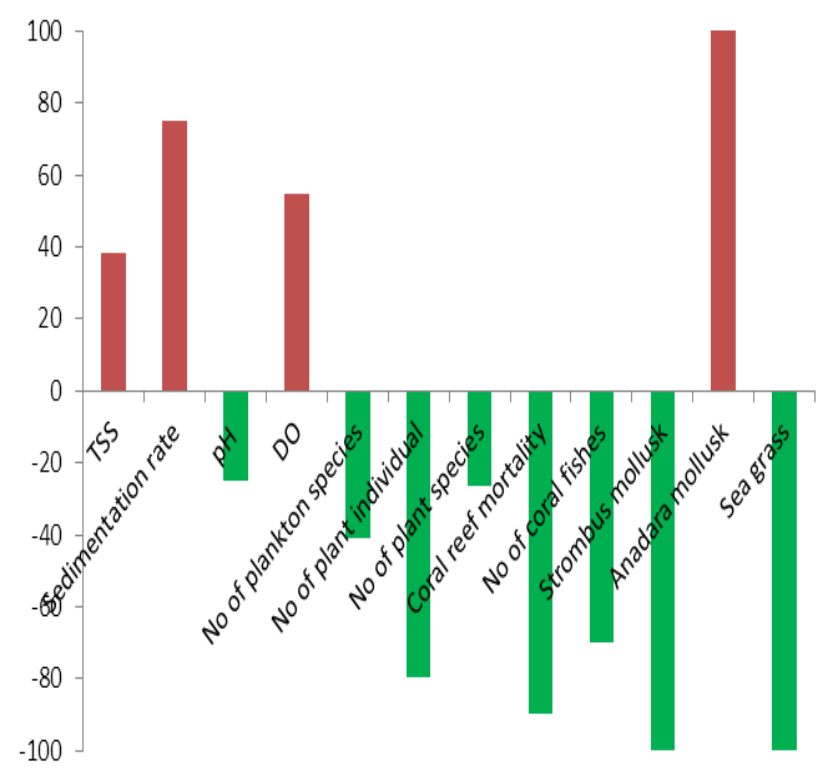

Fig. 2. Increase and decrease percentage of water quality and offshore biotas [20].

In another study, offshore mining was found to cause a $40 \%$ reduction of the number plankton species [18]. The number of species of seagrass in mined water was about $70 \%$ of the number in less mined water [18]. The dominant substrate in mined water was sand and rubble, in contrast to macroalga Halimeda sp. in less mined water [18].

The number of coral reef-associated fish in mined water was $30 \%$ of that in less mined water [18]. Coral reef life coverage was less than $25 \%$ in mined water compared to more than $90 \%$ in less mined water [18]. However, the growth rate of the coral reef species Acropora digitata transplanted to Teluk Limau Beach, Bangka, was 2.2-2.4 mm/month [22].

Because of floating small-scale artisanal tin mining units (TI apung), the number of fish caught has decreased, causing some fishermen not to go fishing, and no need to go further with no guarantee of a good catch [23]. The habitat changes have caused the economic benthic mollusc species Laevistrombus canarium L. (siput gonggong) of the family Strombidae to be replaced by the bivalve species Anadara granosa [24]. Small pelagic and demersal fish production decreased at three offshore mined sites in three regencies over the period 2009-2010 across the island, from $10-70 \%$ [19].

\section{Soil degradation and inland biotas}

Alluvial tin deposits - cassiterite $\left(\mathrm{SnO}_{2}\right)$ - were revealed after stripping the vegetation above the upper soil and removing the non-tin deposit overburden. The extraction is done by pouring a large volume of highly pressured water over the sediment. Heavy tin ore separated from light material by gravity. Non-tin sediment settles in a lower area with acidic $\mathrm{pH}$.

Dredger exploits tin deposits located offshore up to $70 \mathrm{~m}$ depth with bucket wheel dredging. ASM use small traditional gravel pumps to pump tin-ore deposits to floating dredge units (TI apung) or modified small fishing boats.

Inland mining decreases soil properties, changing sand faction up to $97 \%$ (Table 2). The concentrations of phosphate, potassium and sodium in undisturbed land are higher than in mined soil, and are gradually decreasing as the site is abandoned [5]. C-organics are less than $2 \%$, and the cation-exchange capacity (CEC) of tin-mined lands is very low $(0.4-3.9$ units $)$ [5]. The soil temperature may reach $45^{\circ} \mathrm{C}$ during the day [25], and evaporation on sandy tailings may reach $4 \mathrm{~L} / \mathrm{m}^{2}$ /day or double than of undisturbed soil [26].

Table 2. Soil properties of 0-, 7-, 11-, 38- year old tin-mined land, and riparian forest [7].

\begin{tabular}{|c|c|c|c|c|c|c|c|c|c|}
\hline \multirow{2}{*}{ Sites } & Sand & Silt & Clay & $\mathrm{pH}$ & $\mathrm{C}$ & $\mathrm{N}$ & $\mathrm{P}_{2} \mathrm{O}_{5}$ & $\mathrm{~K}_{2} \mathrm{O}$ & $\mathrm{CEC}$ \\
\cline { 2 - 10 } & \multicolumn{3}{|c|}{$(\%)$} & \multicolumn{2}{|c|}{$\mathrm{H}_{2} \mathrm{O}$} & \multicolumn{2}{|c|}{$(\%)$} & \multicolumn{3}{|c|}{$(\mathrm{mg} / 100 \mathrm{~g})$} \\
\hline 0 & 94 & 2 & 4 & 4.8 & 0.2 & 0 & 2 & 3 & 0.4 \\
\hline 7 & 94 & 4 & 3 & 4.8 & 1 & 0.1 & 49 & 3 & 3.3 \\
\hline 11 & 83 & 5 & 13 & 4.9 & 0.2 & 0 & 11 & 4 & 2 \\
\hline 38 & 96 & 2 & 2 & 5.1 & 0.3 & 0 & 5 & 2 & 1 \\
\hline forest & 78 & 13 & 10 & 4.7 & 1.6 & 0.2 & 22 & 5 & 5.8 \\
\hline
\end{tabular}

$\mathrm{C}$ (Walk \& Black); N (Kjeldahl); Cation-exchange (NH4Acetate $1 \mathrm{~N}, \mathrm{pH} 7)$; $\mathrm{CEC}(\mathrm{Ca}+\mathrm{Mg}+\mathrm{K}+\mathrm{Na})$

The water and the sediment from the washing process bring acidic material, which may reach the $\mathrm{pH}$ below 3. The acidity negatively affects soil flora and fauna [5]. A river that receives tin sedimentation has nearly $30 \%$ less fish species compared to a river free from tin mining [27].

Mining activity changes the vegetation structure and composition. The vegetation structure after 38 years of natural succession on old tin-mined land was less than $2 \%$, similar to that of a riparian forest on Bangka Island [5] (Table 3). The number of arbuscular mycorrhizal fungi (AMF) spores increases with the abandonment of tin-mined land, and the number of phosphate solubilising bacteria (PSB) shows different readings with the period of abandonment [5] (Table 4).

Land recovery and coral reef transplantation are costly. The revenue from tin through land function change is lower than for non-mining land uses: protected forest, rubber plantation and beach [20]. The expenditure to convert one hectare of previously tin-mined site into rice field is estimated at Rp. 31 million, with the land preparation component representing the major portion, and almost half of the costs are for soil amendment [6]. 
Table 3. Number of individuals (A), species (B), and families (C) of 0-, 7-, 11-, 38-year old tin-mined land and riparian forest [7].

A. Number of individual per hectare

\begin{tabular}{|c|r|r|r|r|r|}
\hline \multirow{2}{*}{ Sites } & \multicolumn{5}{|c|}{ Number of individuals / ha } \\
\cline { 2 - 6 } & seedlings & saplings & poles & \multicolumn{1}{c|}{ trees } & \multicolumn{1}{c|}{ total } \\
\hline 0 & 0 & 0 & 0 & 0 & 0 \\
\hline 7 & 890 & 0 & 0 & 0 & 890 \\
\hline 11 & 1675 & 45 & 0 & 0 & 1720 \\
\hline 38 & 2125 & 55 & 0 & 0 & 2180 \\
\hline forest & 2665 & 4155 & 305 & 170 & 7295 \\
\hline
\end{tabular}

B. Number of species

\begin{tabular}{|c|r|r|r|r|r|}
\hline \multirow{2}{*}{ Sites } & \multicolumn{5}{|c|}{ Number of species } \\
\cline { 2 - 6 } & seedlings & saplings & poles & \multicolumn{1}{|c|}{ trees } & \multicolumn{1}{|c|}{ total } \\
\hline 0 & 0 & 0 & 0 & 0 & 0 \\
\hline 7 & 6 & 0 & 0 & 0 & 6 \\
\hline 11 & 7 & 2 & 0 & 0 & 8 \\
\hline 38 & 15 & 1 & 0 & 0 & 16 \\
\hline forest & 42 & 66 & 24 & 11 & 85 \\
\hline
\end{tabular}

C. Number of families

\begin{tabular}{|c|r|r|r|r|r|}
\hline \multirow{2}{*}{ Sites } & \multicolumn{5}{|c|}{ Number of families } \\
\cline { 2 - 6 } & seedlings & saplings & poles & trees & total \\
\hline 0 & 0 & 0 & 0 & 0 & 0 \\
\hline 7 & 4 & 0 & 0 & 0 & 4 \\
\hline 11 & 4 & 2 & 0 & 0 & 5 \\
\hline 38 & 12 & 1 & 0 & 0 & 13 \\
\hline forest & 24 & 30 & 14 & 8 & 44 \\
\hline
\end{tabular}

Table 4. Number of phosphate solubilizing bacteria (PSB) and arbuscular mycorrhizal fungus (AMF) of 0-, 7-, 11-, 38-year old tin-mined land and riparian forest [7].

\begin{tabular}{|c|c|c|c|c|}
\hline Sites & $\begin{array}{c}\text { PSB (10 } \\
\text { c/ g soil) }\end{array}$ & $\begin{array}{c}\text { AMF } \\
\text { spores/ 50 g } \\
\text { soil }\end{array}$ & $\begin{array}{c}\text { AMF } \\
\text { genera }\end{array}$ & $\begin{array}{c}\text { Glomus } \\
\text { spp. } \\
\text { (\%) }\end{array}$ \\
\hline 0 & 5 & 1 & 1 & 100 \\
\hline 7 & 10.3 & 69 & 4 & 67 \\
\hline 11 & 6 & 87 & 4 & 59 \\
\hline 38 & 3.2 & 372 & 3 & 95 \\
\hline forest & 7 & 30 & 4 & 57 \\
\hline
\end{tabular}

\section{Physiological characters}

Reclaimed mined land is a highly variable and often challenging environment for the establishment of plants. Although sites differ greatly depending on climate, local geology and reclamation methods there are several characteristics that are commonly encountered on reclaimed mines: relatively low water holding capacity due to coarsely textured soils with little or no organic content, and low nutrient availability.

Species that have been widely adopted for mine reclamation are likely to be ones that are tolerant of a wide range of environmental conditions, and in particular, those that are tolerant of low water and nutrient availability [28].

For water stressed environments, the most droughtadapted species at the individual plant scale has the lowest daily transpirational water consumption [29]. Transpiration reduction also means increasing water use efficiency [30] which may show better adaptability in unfavorable soil conditions. Other species may adapt to drought through morphological changes such as leaf size [31] or possibly anatomical characters [8] rather than through physiological mechanisms.

Although rapid growth of vegetation is often cited as a desirable characteristic to control erosion on reclaimed sites, we found that the most frequently used species tended to have a moderate growth rate. Only Trifolium pratense L. showed higher values that are within the typical reported range for that species [32] (Table 5).

Better able to endure the stressful, low nutrient environments of mine sites, species of moderate growth rate may have been favored for reclamation due to their ability to persist and spread. This finding provides a starting point for further testing. 
Table 5. Summary of traits potentially desirable in reclamation ground covers in Eastern United States [28].

\begin{tabular}{|l|c|c|c|c|c|c|c|c|}
\hline & A & B & C & D & E & F & G & H \\
\hline T. pratense & $\sqrt{ }$ & $\sqrt{ }$ & $\sqrt{ }$ & $\sqrt{ }$ & $\sqrt{ }$ & $\sqrt{ }$ & $\sqrt{ }$ & $\sqrt{ }$ \\
\hline H. esculentus & $\sqrt{ }$ & $\sqrt{ }$ & $\sqrt{ }$ & & & $\sqrt{ }$ & $\sqrt{ }$ & $\sqrt{ }$ \\
\hline T. repens & $\sqrt{ }$ & $\sqrt{ }$ & $\sqrt{ }$ & & & $\sqrt{ }$ & $\sqrt{ }$ & $\sqrt{ }$ \\
\hline L. multiflorum & & $\sqrt{ }$ & $\sqrt{ }$ & & $\sqrt{ }$ & $\sqrt{ }$ & $\sqrt{ }$ & \\
\hline L. corniculatus & & & $\sqrt{ }$ & $\sqrt{ }$ & & $\sqrt{ }$ & $\sqrt{ }$ & $\sqrt{ }$ \\
\hline B. napus & $\sqrt{ }$ & $\sqrt{ }$ & & & & $\sqrt{ }$ & $\sqrt{ }$ & \\
\hline B. perviridis & $\sqrt{ }$ & $\sqrt{ }$ & $\sqrt{ }$ & & & & $\sqrt{ }$ & \\
\hline L. perenne & $\sqrt{ }$ & & $\sqrt{ }$ & $\sqrt{ }$ & & & & $\sqrt{ }$ \\
\hline P. virgatum & & & $\sqrt{ }$ & $\sqrt{ }$ & & $\sqrt{ }$ & $\sqrt{ }$ & \\
\hline V. unguiculata & & $\sqrt{ }$ & & $\sqrt{ }$ & & $\sqrt{ }$ & $\sqrt{ }$ & \\
\hline D. glomerata & & & $\sqrt{ }$ & $\sqrt{ }$ & & $\sqrt{ }$ & & \\
\hline P. fagopyrum & & $\sqrt{ }$ & $\sqrt{ }$ & & & $\sqrt{ }$ & & \\
\hline S. scoparium & & & $\sqrt{ }$ & & & $\sqrt{ }$ & & $\sqrt{ }$ \\
\hline S. nutans & $\sqrt{ }$ & & $\sqrt{ }$ & & & $\sqrt{ }$ & & \\
\hline A. germination $>30 \%$, & & & & \\
\hline
\end{tabular}

$\mathrm{A}=$ germination $>30 \%, \mathrm{~B}=$ cover $>50 \%$ within 2 weeks, $\mathrm{C}=$ number of germination $\mathrm{x} \mathrm{pH}, \mathrm{D}=$ number of cover $\mathrm{x}$ soil type, $\mathrm{E}=$ number of height $\mathrm{x}$ soil type, $\mathrm{F}=$ number of transpiration $\mathrm{x}$ soil type, $\mathrm{G}=$ low transpiration rate, $\mathrm{H}=$ foliar pigments $>0.4$ $\mathrm{mg} / \mathrm{g}$

\section{Conclusions}

The mining activities increase the wealth of the community, but the other hand they change and decrease the environmental stability, and socio economic impact stimulate horizontal conflicts. Offshore mining reduced water quality, change sea bed caused the change of biodiversity, and increase the mortality of coral reefs and their associated fishes. Inland mining activity reduces biodiversity and causes floods and damages infrastructure.

While the more economic species such as rubber, oil palm, and some fruit species are demanded, planting local tree species is challenging. An evaluation with local tree species concluded that best adapted species based on anatomical and physiological measurements was not those that showed the best performance in the field.

The work of finding physiological characteristics to predict ground cover success on mine reclamation sites has being conducted. Plant height and cover, transpiration rate, and foliar pigments may be used to select plant adaptability to mined soil. Species most widely used in reclamation tended to be perennials of moderate rate.
The first author gratefully acknowledges the funding of this research by Directorate General of Higher Education, Republic of Indonesia (Hibah Bersaing 092/SP2H/PP/DP2M/ III/2007;086/SP2H/PP/DP2M/III/2008), and to thank Fulbright for funding the research (68150141). The first author would like to thank Department of Forestry, Wildlife and Fisheries, University of Tennessee kindly provided facilities to undertake the research. University of Bangka Belitung is thanked for its permission allowing the first author to conduct research. The authors acknowledge Mr. A. Akbar and Ms. W.E.A. Putri, Dr. Z.Q. Liu, and Mr. J. Seaton for the valuable data and help.

\section{References}

1. IDH Tin working group communiqué - To share recent study findings and consult Indonesian stakeholders about their sustainability views and priorities for action (2013).

2. Bangka Pos, 2013, Idil: arogansi bupati akan dibayar mahal. Bangka Pos 20 Maret 2013, viewed 19 April 2013.

3. International Tin Research Institute (ITRI) Indonesia's position in the global tin industry. Proceedings ITRI Indonesia Tin Forum, 11 December 2013, Pangkalpinang (2013).

4. Walhi - Friends of the Earth Indonesia, Mari buat Bangka Belitung lebih baik. Proceedings ITRI Indonesia Tin Forum, 11 December 2013, Pangkalpinang, Indonesia.

5. E. Nurtjahya, D. Setiadi, E. Guhardja, M. Muhadiono, Y. Setiadi, Succession on tin-mined land in Bangka Island, Blumea, 54 (2009), no. 1-3, pp. 131-138.

6. E. Nurtjahya, M.M. Nur, E. Mulyono, Rice field cultivation on tin-mined land in Bangka Island, Indonesia. Proceedings of Mine Closure 2009, A.B. Fourie, and M. Tibbett (eds), September 2009, Perth,2009 Australian Centre for Geomechanics, Pe rth, pp. 549-560.

7. E. Nurtjahya, Revegetasi lahan pasca tambang timah dengan beragam jenis pohon lokal di Pulau Bangka, Dissertation, Bogor, Institut Pertanian Bogor, 163 pp, (2008).

8. E. Nurtjahya, R. Robika, D. Dorly, Can anatomical and physiological characters predict plant adaptation on tin-mined land in Bangka Island? Proceedings of the $6^{\text {th }}$ International Conference on Mine Closure 2011, A.B. Fourie, and M. Tibbett and A. Beersing (eds), September 2011, Alberta, Canada,2011 Australian Centre for Geomechanics, Perth, pp. 75-83.

9. Badan Pusat Statistik (BPS), Bangka Belitung dalam Angka, Pangkalpinang (2012), Indonesia.

10. PT Timah Tbk, ANDAL, RKL, dan RPL. Kegiatan penambangan timah dan pasir laut di perairan Pulau Bangka Kabupaten Bangka, Propinsi Sumatera Selatan (1997).

11. Z.D. Sesták, J. Čatskŷ, P.G. Jarvis, Determination of chlorophylls a and $\mathrm{b}$, in Plant photosynthetic production: Manual of Methods, Z. Sesták, J. Čatskŷ, and P.G. Jarvis, eds., Junk NV, The Hague
(1971),
pp.
$672-701$.
B.H. 
12. Davies, Analysis of carotenoid pigments. In: T.W. Goodwin (ed.) Chemistry and Biochemistry of Plant Pigments, pp. 489-532. Academic Press, New York, (1965).

13. L. Juniarti, Disharmonisasi keluarga pada pekerja tambang inkonvensional (TI) di Dusun Parit 19 Kecamatan, Dissertation, Jurusan Sosiologi, Universitas Bangka Belitung, Pangkalpinang, Indonesia, (2014).

14. Indra, Tambang inkonvensional dan implikasinya terhadap perilaku sosial masyarakat di Desa Tempilang Kabupaten Bangka Barat, Dissertation, Jurusan Sosiologi, Universitas Bangka Belitung, Pangkalpinang, Indonesia, (2013).

15. B. Romeo, Tambang inkonvensional dan perubahan perilaku ekonomi masyarakat Desa Semulut Kecamatan Jebus, Dissertation, Jurusan Sosiologi, Universitas Bangka Belitung, Pangkalpinang, Indonesia, (2011).

16. E. Erman, Dampak penambangan timah dan respon masyarakat local. Proceeding ITRI Indonesia Tin Forum, 11 December 2013, Pangkalpinang, Indonesia, (2013).

17. E. Nurtjahya, F. Agustina, W.A.E. Putri, Neraca ekologi penambangan timah di Pulau Bangka Studi kasus pengalihan lahan di ekosistem darat, Berkala Penelitian Hayati, 14(1) (2008), pp. 29-38.

18. E. Nurtjahya, F. Agustina, A. Akbar, Kajian manfaat sosial ekonomi penambangan timah inkonvensional dan kerusakan lingkungan dan keanekaragaman hayati yang ditimbulkannya di Pulau Bangka, Laporan Penelitian Hibah Bersaing, Universitas Bangka Belitung (2008), 70 p.

19. E. Nurtjahya, F. Agustina, Managing the socioeconomic impact of tin mining on Bangka Island, Indonesia - preparation for closure. Proceedings Mine Closure 2015, A.B. Fourie and M. Tibbett, L. Sawatsky and D. Van Zyl (eds), Juni 2015, Vancouver,Canada,Australian Centre for Geomech anics, Perth, pp. 817-826.

20. E. Nurtjahya, U. Umroh, F. Agustina, Impact of tin mining on the biota of Bangka Island, Indonesia - a proof to convince the tin supply chain of smartphone companies. Proceedings Mine Closure 2014, A.B. Fourie, M. Tibbett, and I. Weiersby (eds), October 2014, Johannesburg, SouthAfrica,Australian Centre for Geomechanics, P erth (to be published).

21. H. Wahyuni, S.B. Sasongko, D.P. Sasongko, Kandungan logam berat pada air, sedimen dan plankton di daerah penambangan masyarakat Desa Batu Belubang Kabupaten Bangka Tengah, in Proceedings Seminar Nasional Pengelolaan Sumberdaya Alam dan Lingkungan (2013), 489494.
22. H. Sodikin, Pertumbuhan Acropora digitata pada transplantasi karang di pantai Teluk Limau Sungailiat Provinsi Kepulauan Bangka Belitung, Dissertation, Pangkalpinang: Jurusan Perikanan Universitas Bangka Belitung (2011), 36 p.

23. P. Pratama, Alih profesi nelayan menjadi penambang timah di Lingkungan Nelayan 2 Sungailiat, Dissertation, Jurusan Sosiologi, Pangkalpinang: Universitas Bangka Belitung (2014).

24. F. Yulianda, F. Achmad, A.H. Armin, H. Sri, K. Kusharjani, Ekologi ekosistem perairan laut tropis, PUSDIKLAT Kehutanan - Departemen Kehutanan RI, Bogor: SECEM - Korea International Cooperation Agency (2009).

25. E. Nurtjahya, D. Setiadi, E. Guhardja, M. Muhadiono, Y. Setiadi, Revegetation of tin-mined land using various local tree species in Bangka Island, Indonesia. Proceedings of the 2008 National Meeting of the American Society of Mining and Reclamation New Opportunities to Apply Our Science, R.I. Barnhisel (ed), June 2008, Lexington, USA, ASMR, pp. 739-755.

26. E. Nurtjahya, Ex tin-mined research - a local tree species search (2010) (unpublished).

27. K. Muslih, E.M. Adiwilaga, S. Adiwibowo, Pengaruh penambangan timah terhadap keanekaragaman ikan sungai dan kearifan local masyarakat di Kabupaten Bangka. Prosiding Pertemuan Ilmiah Tahunan MLI I (2013).

28. E. Nurtjahya, J. Franklin, Some physiological characteristics to estimate species potential as a mine reclamation ground cover. Int. J. Min. Reclam. Environ (2016) (to be published).

29. C. Tong, J.-Z. Gong, R. Marrs, I. Zhang, W.-Q Wang, Pattern of transpiration of four shrub species and water consumption from shrub stands in an eco-reclamation catchment in northwest China, Arid Land Res. Manag. 22 (2008), pp. 242-254.

30. A.M. Gonzalez-Rodriguez, Z. Baruch, D. Palomo, G. Cruz-Trujillo, M.S. Jimenez, D. Morales, Ecophysiology of the invader Pennisetum setaceum and three native grasses in the Canary Islands, Acta Oecol. 36 (2010), pp. 248-254.

31. F.M. DaMatta, Exploring drought tolerance in coffee: a physiological approach with some insights for plant breeding, Braz. J. Plant Physi. 16 (2004), pp. 1-6.

32. L. Simova-Stoilova, K. Demirevska, A. KingstonSmith, U. Feller, Involvement of the leaf antioxidant system in the response to soil flooding in two Trifolium genotypes differing in their tolerance to water logging, Plant Sci. 183 (2012), pp. 43-49.

\footnotetext{
*Corresponding author: eddy_nurtjahya@yahoo.com
} 